\title{
THE FAREWELL AND SHAKESPEARE
}

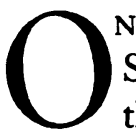

NE editor of Shakespeare pronounces Rich's "Apolonius and Silla" a "coarse, repulsive novel" and expresses the (vain) hope that Shakespeare never read it because "his hours were more precious to us than those of any poet who ever lived; it would be grievous to think that he wasted even half a one over Apolonius and Silla."' But in his tastes Shakespeare was Elizabethan, not Victorian, and more apt to be amused than repulsed by the "coarse, unrefined atmosphere" which in the Victorian critic's opinion the Faremell exudes. Shakespeare was a busy, astute searcher for plots in Painter's Palace and other works of fiction, and in his search he was not one to overlook an Elizabethan best-seller like Rich's Faremell. In fact, if a theory to be examined presently is correct, he was the first of the long procession of dramatists to explore Rich's collection, and he emerged with at least part of a plot as early as $\mathrm{I} 597$ or I 598 .

Though he did not treat Rich with the respect he accorded Holinshed or North, the Faremell seems to have been as estimable in his judgment as, say, "Giletta of Narbonne" or Rosalynde. There is evidence that certain Elizabethans laughed at the Faremell (for reasons not envisaged by its author) but read it. Shakespeare may have laughed too. One can imagine a worse fate for a group of short stories than to be laughed at, read-and used by William Shakespeare.

\section{A Twelfth Night}

Despite the Victorian hope quoted above, Shakespeare conferred immortality on Rich and his Faremell by borrowing most of the plot of Tmelfth Night from Rich's second tale and a bit from the fifth as well. Presumably the first to notice the connection between the comedy and "Apolonius" was the antiquary Octavius Gilchrist. He shared his discovery with Edmond Malone "in a very modest and respectful letter" in 1806 , and Malone adopted the discoverer's opinion in the matter. ${ }^{2}$

\footnotetext{
${ }^{1}$ For these and other adverse comments on the story, see the New Variorum Twelfth Night, ed. H. H. Furness (Philadelphia, 1901), pp. xvii, 327.

${ }^{2}$ See The Plays and Poems of William Shakespeare, ed. Edmond Malone and James Boswell (London, 1821), XI, 321.
} 
xlviii

\section{INTRODUCTION}

Both were anticipated in print by J.P. Collier in $1820 .{ }^{\mathrm{I}}$ Since that date, agreement that Shakespeare employed "Apolonius" has been all but unanimous. Since the relationship of Tpelfth Night to its main source has been diligently studied time and time again, one may forbear to restudy it here, though the verbal parallels between the play and the story, including a few not detected before, appear in the notes.

Because Shakespeare knew "Apolonius," it has very often been reprinted, while the rest of the Farewell has suffered neglect. Few have read all Rich's stories from beginning to end, and fewer still have read them through with Shakespeare in mind. One of the latest to do so was W. A. Neilson, and the result of his reading fifty years ago was the discovery that an episode in "Two Brethren," Rich's fifth tale, inspired Malvolio's incarceration in the dark room. ${ }^{2}$ One editor of Twelfth Night ends his consideration of the sources of the comedy with the sigh, "After all, for our relief, no one has yet found Shakespeare a debtor to anyone for Malvolio."3 Perhaps not; but he was indebted to Rich for Malvolio's most hilarious predicament-and possibly for his yellow stockings and for Sir Toby's sink-a-pace as well. ${ }^{4}$

\section{B The Merry Wives of Windsor}

Another scholar who persisted beyond Rich's rather prolix first story observed that the tale which inspired Malvolio's humiliation in the dark room also displays remarkable similarities to The Merry Wives of Windsor. ${ }^{5}$ In her study of Rich's fifth tale and the comedy Mrs. Bruce considers the six fabliaux (not counting Rich's) usually cited as analogues to The Merry Wives, shows how each of the six corresponds to the play, indicates numerous details which are common to Shakespeare and Rich but absent from the six, and asserts that in "certain points, though not in all, Riche's tale is nearer to Shakespeare's play than are any of the other stories." Indeed, only "Riche's tale ... presents the particular combination of elements which reappears in certain portions of Fal-

\footnotetext{
'In The Poetical Decameron (London, 1820), II, 133-63.

${ }^{2}$ See the Atlantic Monthly, LXXXIX (1902), $717 \mathrm{f}$.

${ }^{3}$ See Twelfth Night, ed. Sir Arthur Quiller-Couch (Cambridge, 1930), p. xiv.

4 See the notes on 5. 12-16. 12, 146. 37, 208. 26.

5 Dorothy H. Bruce, "The Merry Wives and Two Brethren," SP, XXXIX (1942),
} 265-78. 
xlix

\section{THE Farepell AND SHAKESPEARE}

staff's story, and nowhere else." After commenting on Rich's "patchwork procedure" in putting his tales together, ${ }^{\mathrm{I}}$ she suggests that instead of collecting "details from half a dozen tales" and from them devising a plot which "happened to correspond closely to Riche's version," Shakespeare "remembered and used Riche's 'fift historie." She concludes that Shakespeare and Rich "have enough in common to establish strong evidence of Shakespeare's knowledge" of "Two Brethren." In support of her arguments she presents abundant parallels in plot and language. ${ }^{2}$

There is little to add to her observations except that the action of both the play and the novel occurs in England, a locale not common in sixteenth-century drama or fiction. Though Cymbeline is set partly in Britain, The Merry Wives is the only one of Shakespeare's sixteen comedies in which English characters admittedly bustle about in an Elizabethan English town. "Two Brethren" is also an exception to the rule that Rich and his fellow-novelists preferred to follow. The action of seven of the eight tales in the Farewell takes place in exotic surroundings. Only the heroine of Rich's fifth tale holds court in England.

Also worth noting are two speeches in The Merry Wives in which Shakespeare seemed to glance at Rich. Into the busy mouth of Mistress Quickly he put the words of a brief passage from the Farewell which was so notorious that it was unquestionably quoted and requoted by Rich's contemporaries. As a result of the notoriety, Rich came to be known to certain Elizabethans as "honest Barnaby," so that the very mention of the words honest and honesty may have directed the minds of some to the captain. ${ }^{3}$ In 1598 , the year to which most scholars assign The Merry Wives, honest Rich published A Martiall Conference . . . Newly Translated out of Essex [Rich's home county] into English. ${ }^{4}$ The title may explain a bit of Pistol's fustian. When Falstaff boasts of Mistress Ford's "leer of invitation," his brag elicits from Pistol the remark, "He hath studied her well and translated her well—out of honesty into English."5

\footnotetext{
${ }^{1}$ For the many sources of "Two Brethren," see below, pp. 342-46.

2 These, plus a few others that I have been able to supply, are noticed throughout the notes, pp. 290-306.

${ }^{3}$ For discussion of the passage and Rich's sobriquet see below, pp. liv-lviii.

4 Only the title-page in the British Museum (Harleian 5900, fol. 38 ) is now known.

${ }^{5} \mathrm{I}$. iii. $54 \mathrm{f}$. If this is a timely allusion to Rich and his work, it helps confirm 1598 as the proper date for The Merry Wives in its present form.
} 


\section{INTRODUCTION}

But to those who are comparing "Two Brethren" and The Merry Wives, the most impressive speeches in the play are the ones which seem to echo Rich's very words. ${ }^{I}$ In the light of these speeches alone some might consider Mrs. Bruce's conclusion too modest. After studying the array of parallels, verbal and other, which she detects, many may conclude that Rich's story is not merely a striking analogue to the comedy but a source for it. If so, then the Faremell was grist to the miraculous mill first in 1598 , about two years before Rich's "Apolonius" (after some exceeding fine grinding) yielded Twelfth Night, and Shakespeare exploited the dramatic potentialities of the Faremell earlier than any other known playwright.

"Two Brethren," the most fetching of Rich's tales, deserves any attention Shakespeare may have paid it. It is almost as amusing a fabliau as The Merry Wives is a play. The personages of the tale move on a comic level as high-or, rather, as deliciously low-as the one Falstaff lards. After a perusal of their deeds, most readers will allow, I think, that whatever time Shakespeare consumed in reading Rich's fifth tale was time well spent.

\section{c Othello}

In the notes to the present edition appear scores of quotations from twenty-nine plays by Shakespeare which passages in the Farewell illuminate in one way or another. No sensible man would pretend that Shakespeare borrowed from Rich every idea or phrase thus illuminated. But like the parallels between Twelfth Night and "Apolonius" and The Merry Wives and "Two Brethren," those between Othello and Rich's first two stories are sufficiently abundant and close to deserve treatment here, especially since Shakespeare clearly demonstrated his knowledge of Rich's second tale in Twelfth Night. Whether the series of similarities between Othello and the stories amounts to proof that Shakespeare drew from Rich certain incidents for one of his greatest tragedies each reader may decide for himself. In my opinion the similarities are, at the least, too interesting to be overlooked.

They are especially numerous in the first act and the first scene of the second act, where Shakespeare departs widely from his principal source,

${ }^{1}$ See particularly the note on 140. 18-141. 25. 


\section{THE Faremell AND SHAKESPEARE}

Cinthio's account of the Moor and Disdemona (Gli Hecatommithi, Decade III, Novel 7). According to Cinthio, the Moor "embarked on board the galley with his wife and all his troops, and setting sail, they pursued their voyage, and with a perfectly tranquil sea arrived safely at Cyprus."I The "perfectly tranquil sea" is a far cry from the "desperate tempest" which scatters Othello's ships and destroys the Turkish fleet.

Othello's maritime trials are foreshadowed in Rich's second tale. Here Apolonius' fleet is "deseuered" by a "tempest whiche sodainly fell," and the hero manages to reach Cyprus, where he is "worthily receiued by Pontus Duke and gouernour of the same Ile" (68. I4-I7). In Cinthio, incidentally, there is no mention of a governor who might have suggested Shakespeare's character Montano, the governor of Cyprus who is to be relieved by Othello, and who awaits the arrival of the seafarers in Act II, Scene I.

The parallels between the first act of Othello and "Sappho Duke of Mantona," Rich's first tale, are more plentiful and on the whole more remarkable. Shakespeare's plot usually corresponds to Rich's in precisely those details which Cinthio lacks. In the novella a peaceful changing of the troops at Cyprus rather than an imminent invasion by the Turks prompts the Signoria, the ruling body of Venice (no duke appears), to put the Moor in charge of the relieving forces. Though the Moor has proved his martial valor and enjoys the esteem of the Signoria, Cinthio does not specify that he has won his reputation in campaigns against the Turks or that he is of unique military value to Venice. His courtship of Disdemona is not described. Disdemona's parents try to persuade her to choose another husband, but she and the Moor marry and live happily for some time in Venice. There is no elopement and consequently no pursuit, apprehension, and accusation by an enraged father and no trial of the bridegroom. To this relatively peaceful and leisurely beginning Shakespeare's feverish and violent first act presents a conspicuous contrast.

Rich and Shakespeare, on the other hand, share the following details. A Christian ruler who must meet alarming threats from invading Turks organizes a campaign (49.25-5I. I8; I. iii). As general of the expeditionary forces the ruler, a duke, appoints a leader famous for his

I J. E. Taylor's translation, New Variorum Othello, ed. H. H. Furness (Philadelphia, I886), p. 378. 
lii

\section{INTRODUCTION}

victories against the Turks and indispensable to the government in the military crisis $(24$. 3-7, 50. 13-18, 5 I. I7 f.; I. i. 148-54, ii. 17-34, iii. 48 f., iii. 222-26). After a clandestine courtship (45. I3-I8; I. i. I66) a couple elopes and is pursued by the angry, revenge-bent father of the bride (46. 23-27; I. i. 176-83). Apprehending his son-in-law, the father accuses him of stealing the daughter and demands justice (53. I3-2I; I. ii. 62-75, iii. 60). Much is made of a trial scene before the reigning duke, who appoints the father, a man of power and influence, judge of his own case (54. I I f., 59. I 5-63. I8; I. iii. 65-70). The accused man admits the elopement (59. 16-18; I. iii. 77-79), and the presiding duke and the spectators at the trial accord their sympathy to the defendant (53. 22-24, 59. I9-2I ; I. iii. 73). The duke addresses the father in the son-in-law's behalf $(59.25-35 ;$ I. iii. I 7 I-75) and summons the daughter to give her testimony $(54.5-9,59$. I3 f.; I. iii. I20), which is designed to exonerate her husband.

If these not inconsiderable resemblances between the tragedy and Rich's stories are due to something more than coincidence, then Shakespeare made use of the second tale for Twelfth Night about I 600 and again for Othello about I604, when he gleaned from "Apolonius" a few details which had been of no use to him in the comedy and from "Sappho" much matter which was serviceable in his first act. And, if so, Shakespeare's selection from the Faremell (it goes without saying) was brilliant and purposeful: on the stage a grieved, outraged, pursuing father is a more gripping spectacle than quietly disapproving parents, especially when he catches up with the runaways; trial scenes are always good theater; a military crisis which threatens to separate bride and groom and sends the hero packing on the very night of his elopement, apprehension, trial, and acquittal induces rather more excitement than a routine changing of the guard; and there is much to be said, dramatically, for a furious tempest which tears the hero's ship from the rest of his fleet and allows him, after anxious and suspenseful moments, to arrive safe in his bride's arms at Cyprus. 